\title{
POLA PENCARIAN INFORMASI TENTANG REPRODUKSI SEKSUAL PADA MAHASISWA UNIVERSITAS SRIWIJAYA
}

\author{
Nurly Meilinda ${ }^{1}$, Sena Putra Prabujaya ${ }^{2}$, Krisna Murti $^{3}$ \\ ${ }^{1,2,3}$ Prodi Ilmu Komunikasi, FISIP Universitas Sriwijaya \\ Jl.Palembang-Prabumulih KM 32 Inderalaya Ogan Ilir 30662, Indonesia \\ Email: nurlymeilinda@unsri.ac.id
}

\begin{abstract}
Abstrak
Penelitian ini bertujuan untuk megetahui pola pencarian informasi tentang reproduksi seksual pada mahasiswa di Universitas Sriwijaya. Penelitian ini menggunakan pendekatan kualitatif berdasarkan Model Perilaku Pencarian Informasi Wilson yang terdiri dari perhatian pasif, pencarian pasif, pencarian aktif, dan pencarian berlanjut. Penelitian ini melibatkan wawancara mendalam dengan 12 mahasiswa Universitas Sriwijaya. Studi ini menemukan bahwa mahasiswa di Universitas Sriwijaya cenderung melakukan pola pencarian pasif ketika mencari informasi tantang reproduksi seksual. Namun hal ini tidak berlaku ketika mahasiswa memiliki tanggung jawab, baik secara akademis maupun profesional, karena diketahui mahasiswa dengan tanggung jawab tersebut akan melakukan pencarian aktif dan berlanjut. Studi ini juga menemukan bahwa model Perilaku Pencarian Informasi Wilson masih dapat dijadikan rujukan. Dalam konteks perilaku pencarian informasi mahasiswa Universitas Sriwijaya masih dipengaruhi oleh kondisi psikologis, demografis, peran di masyarakat, lingkungan, dan karakteristik sumber informasi. Penelitian ini juga mengidentifikasi motif dari perilaku pencarian informasi reproduksi seksual pada mahasiswa di Universitas Sriwijaya.
\end{abstract}

Kata Kunci: Pola Pencarian Informasi, Reproduksi Seksual, Mahasiswa

\begin{abstract}
This study aims to determine the sexual reproduction information seeking pattern of Students in Sriwijaya University. It uses a qualitative approach based on Wilson's Model of Information Seeking Behavior that consist; passive attention, passive search, active search, and ongoing search. This research involves in-depth interviews with 12 students of Sriwijaya University. The study found that students at Sriwijaya University tend to perform a passive search pattern in seeking of sexual reproductive information. However this conditions does not apply when the students have responsibilities to fullfil, both academically and professionally, as it is known that the student with such responsibilities will perform an active and ongoing search. The study also found that Wilson's Search Information Behavior model can still be usefull. In the context of information seeking behavior of Student in Sriwijaya University, it was still influenced by psychological conditions, demographics, roles in society, environment, and characteristics of information sources. This study also identifies the motive of sexual reproduction information seeking behavior in students at Sriwijaya University.
\end{abstract}

Keywords: Information Seeking Pattern, Sexual Reproduction, Students 


\section{PENDAHULUAN}

Modernisasi, globalisasi teknologi, dan informasi serta berbagai faktor lainnya turut mempengaruhi pengetahuan, sikap dan perubahan perilaku kehidupan mahasiswa yang kemudian berpengaruh pada perilaku kehidupan kesehatan reproduksi mereka. Segala yang mempengaruhi perilaku kesehatan reproduksi jika tidak segera ditangani dengan seksama akan berdampak pada kesehatan reproduksi mahasiswa. Pendidikan dan infomasi kesehatan reproduksi dan seksual yang kurang pada mahasiswa akan menyebabkan rendahnya pengetahuan dan mempengaruhi sikap mahasiswa yang negatif terhadap masalah kesehatan reproduksi dan perilaku seksual. Besarnya rasa keingintahuan mahasiswa mengenai kesehatan reproduksi mendorong mahasiswa untuk mencari informasi dari berbagai sumber, termasuk teman sebaya, orang tua, sekolah dan media informasi. Situasi tersebut diperburuk dengan adanya kemudahan mahasiswa dalam mengakses informasi tentang seks yang keliru melalui media cetak dan elektronik misalnya majalah, video dan internet.

Hasil Survei Demografi dan Kesehatan Indonesia-Kesehatan Reproduksi Mahasiswa (SDKI-KRR) Tahun 2012 tentang pengetahuan mahasiswa perempuan ditemukan 4,7\% tidak tahu tentang perubahan fisik pubertas anak perempuan dan 10,1\% tidak tahu tentang perubahan fisik pubertas laki-laki. Pada mahasiswa laki-laki ditemukan 11,1\% tidak tahu tentang perubahan fisik pubertas laki-laki dan $21,2 \%$ tidak tahu tentang perubahan fisik pubertas anak perempuan. Informasi tentang kesehatan reproduksi diperoleh pada pendidikan formal maupun diluar pendidikan formal. Diluar pendidikan formal banyak mahasiswa mendiskusikan tentang kesehatan reproduksi bersama teman, "tentang haid pertama pada wanita yaitu 53,6\% dan mimpi basah pada laki-laki yaitu $48 \%$.

Angka aborsi di Indonesia cukup tinggi, mencapai 2,4 juta per tahun. Menurut data BKKBN bahwa aborsi meningkat setiap tahunnya sekitar $15 \%$ dan dari jumlah tersebut sebanyak 800.000 kasus aborsi dilakukan oleh mahasiswa yang masih berstatus pelajar. Data Kota Padang tahun 2012 menyatakan 19\% mahasiswa pernah melakukan hubungan seksual sampai menyebabkan kehamilan. Data Persatuan Keluarga Berencana Indonesia (PKBI) Cemara tahun 2013 menyatakan bahwa 10,5\% mahasiswa Kota Padang berperilaku seksual aktif. Penelitian yang dilakukan tentang Gambaran Penyimpangan Seksual Mahasiswa Sekolah Tingi Ekonomi di Kota Padang Tahun 2013 yang diterbitkan pada Harian Singgalang diperoleh data $16 \%$ mengaku pernah melakukan hubungan seksual. Pada tahun 2014 dalam tulisan Syafril, 45\% Mahasiswa Sekolah Tinggi Ilmu Keguruan Pendidikan Padang nonton film porno, $21 \%$ mahasiswa mengaku sudah melakukan hubungan seksual bebas. Pada tahun 2014 jumlah penderita AIDS Kota Padang pada usia 15-19 tahun ditemukan sebesar $4,55 \%$.

Menurut L.Green perilaku dipengaruhi oleh tiga faktor utama yaitu faktor predisposisi (predisposing factor), faktor pemungkin (enabling factor), dan faktor pendorong (reinforcing factor).14 Pengetahuan kesehatan mahasiswa (predisposing factor) yang kurang menimbulkan implikasi perilaku negatif seperti kehamilan tidak dikehendaki, infeksi menular seksual dan lain sebagainya. Sebagai langkah awal pencegahan, peningkatan pengetahuan mahasiswa mengenai kesehatan reproduksi harus ditunjang dengan materi komunikasi, informasi dan edukasi (KIE) yang tegas tentang penyebab dan konsekuensi perilaku seksual. Selain itu juga perlu diinformasikan tentang yang seharusnya dilakukan dan dilengkapi dengan informasi mengenai sarana pelayanan yang tersedia. Pada saat ini informasi tentang kesehatan reproduksi (enabling factor) disebarluaskan dengan pesan-pesan yang samar dan tidak fokus, terutama bila mengarah pada perilaku seksual. Bimbingan dari orang tua sebagai lingkungan primer dan adanya guru di sekolah sebagai lingkungan sekunder tentang kesehatan reproduksi yang menunjang pengetahuan dan sikap bagi 
mahasiswa menghadapi perubahan yang mereka alami agar mereka siap dan tidak mendapatkan informasi yang salah tentang kesehatan reproduksi (reinforcing factor).

\section{Rumusan Masalah}

Bagaimana Pola Pencarian Informasi Tentang Reproduksi Seksual Pada Mahasiswa Universitas Sriwijaya?

\section{TINJAUAN PUSTAKA}

\section{Model dan Perilaku Pencarian Informasi}

Krikelas (dalam Rosita, 2006: 16) berpendapat bahwa perilaku pencarian informasi adalah kegiatan dalam menentukan dan mengidentifikasikan pesan untuk memuaskan kebutuhan informasi yang dirasakan. Pendapat lebih rinci dikemukakan oleh Drao yang dikutip oleh Luki Wijayanti (dalam Rosita, 2006: 17) mengatakan perilaku pencarian informasi merupakan aktivitas pemakai untuk mencari, mengumpulkan, dan memakai informasi yang mereka butuhkan.

Dalam bukunya Putu Laxman Pendit (2003: 30 - 32) dijelaskan tentang sejarah penelitian perilaku informasi. Penelitian terhadap perilaku penemuan informasi sudah dimulai sejak lama di bidang perpustakaan, misalnya melalui berbagai survei di tahun 1916 di Inggris tentang bagaimana perpustakaan digunakan dan siapa saja yang menggunakannya.

Penelitian yang mulai mengaitkan penggunaan informasi dengan kegiatan sehari-hari mulai dilakukan sejak konferensi yang diadakan The Royal Society Scientific Information tahun 1948 di Inggris. Tentu saja, yang terutama dikaji setelah itu adalah pola penggunaan informasi oleh para ilmuwan, tetapi penekanannya bukan pada si pengguna, melainkan pada jenis-jenis bahan pustaka apa yang paling dibutuhkan dan dicari oleh pengguna. Tujuan utama kajian-kajian di bidang ini adalah untuk mencari tahu bagaimana caranya mengefektifkan penggunaan bahan pustaka yang sudah dibeli dengan biaya besar, dan bagaimana para membujuk ilmuwan untuk lebih banyak menggunakan bahan pustaka.

\section{Model Perilaku Pencarian Informasi Wilson}

Dalam tulisannya, Putu Laxman Pendit (2003: 28 - 30) mengulas tulisan Wilson (2000). Di kalangan peneliti ilmu informasi, Wilson dikenal sebagai pemerhati khusus perilaku pencarian informasi bersama dengan peneliti-peneliti lain seperti Dervin, Kuhlthau, dan ellis. Dalam artikelnya, Wilson berpendapat bahwa penelitian di kalangan perancang dan pembuat system informasi selama ini selalu menyamakan "kebutuhan informasi" dengan bagaiman seorang pemakai sistem berperilaku ketika ia berhadapan dengan sebuah system informasi.

Dalam model perilaku pencarian informasi yang dikemukan oleh Wilson (1996) terdapat Intervening Variable sebagai faktor yang menentukan tingkat keberhasilan dalam memenuhi kebutuhan informasi. Wilson mengemukakan bahwa kebutuhan dasar dapat didefinisikan sebagai psikologis atau kognitif atau afektif. Wilson mencatat bahwa konteks (situasi/keadaan) berasal dari suatu kebutuhan mungkin dari personal, role related (aturan yang berperan) atau environmental (lingkungan) dimana dia tinggal atau bekerja. Dia berpendapat bahwa rintangan yang menghalangi pencarian informasi akan muncul bersamaan dengan konteks (situasi/keadaan). Dan yang dikategorikan termasuk sebagai Intervening Variable itu adalah personal (psikologis dan demografis), role-related (aturan yang berperan)/ interpersonal, environmental (lingkungan), karakteristik sumber informasi.

- Psikologis: Bahwa seseorang yang sedang risau akan memperlihatkan perilaku informasi yang berbeda dibandingkan dengan seseorang yang sedang gembira. 
Dalam penelitian ini, sisi psikologis yang akan dilihat adalah berdasarkan pengetahuan, pola pikir, dan karakteristik emosi.

- Demografi: Dalam arti luas menyangkut kondisi sosial-budaya seseorang sebagai bagian dari masyarakat dalam hal ini. Kelas sosial juga dapat mempengaruhi perilaku informasi seseorang. Dalam penelitian ini akan dilihat kondisi demografi objek penelitian berdasarkan: usia, jenis kelamin dan tingkat pendidikan.

- Role-related (aturan yang berperan)/ interpersonal. Peran ini khususnya dalam hubungan interpesonal ikut mempengaruhi perilaku informasi.

- Lingkungan: Dalam hali ini adalah lingkungan terdekat maupun lingkungan yang lebih luas seperti waktu, kondisi Geografi, serta budaya setempat.

- Karakteristik sumber informasi: Karakter media yang akan digunakan dalam mencari dan menemukan informasi, seperti kemudahan akses, kredibilitas dan saluran komunikasi.

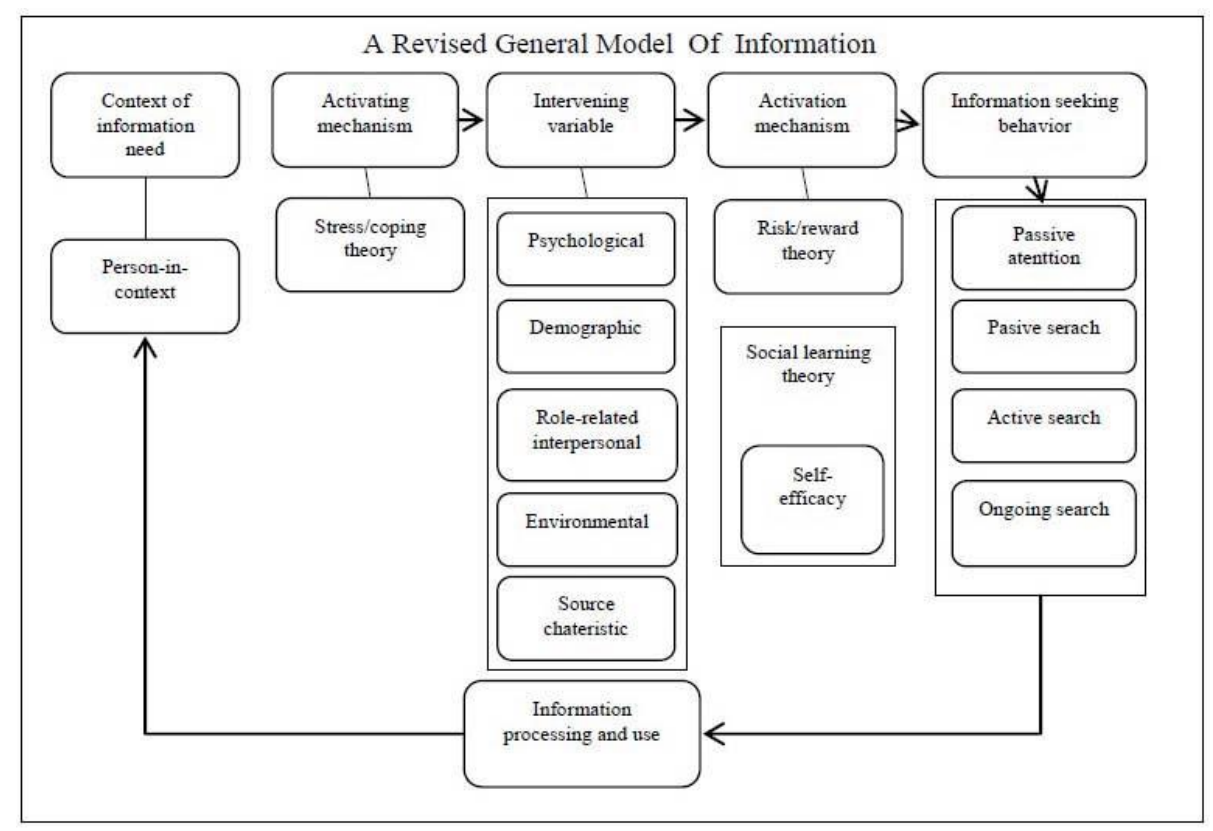

Sumber: looking for information (117: 2002)

\section{Perilaku Pencarian Informasi}

Dalam modelnya, Wilson mengungkapkan empat perilaku pencarian informasi.

a) Perhatian pasif (passive attention)

"...such as listening to the radio or watching television programmes, where there may be no information-seeking intended, but where information acquisition may take place nevertheless."

b) Pencarian pasif (passive search)

"...which seems like a contradiction in terms, but signifies those occasions when one type of search (or other behavior) results in the acquisition of information that happens to be relevant to the individual."

c) Pencarian aktif (active search)

"...which is the type of search most commonly thought of the information science literature, where an individual actively seeks out information."

d) Pencarian berlanjut (ongoing search) 
“...where active searching has already established the basic framework of ideas, beliefs, values, or whatever, but where occasional continuing search is carried out to update or expand one's framework."

\section{Teori Disonasi Kognitif}

Teori disonansi kognitif (cognitive dissonance theory) merupakan salah satu teori kognitif yang mempelajari sikap dengan penkanan pada konsistensi kognitif, lebih khusus tentang bagaimana perilaku memengaruhi sikap, yang diperkenalkan oleh Leon Festinger pada tahun 1957. Teori disonansi kognitif menjelaskan mengenai keyakinan dan perilaku dapat mengubah sikap. Teori ini berfokus pada efek inkonsistensi yang ada diantara kognisikognisi. Teori ini berpendapat bahwa disonansi adalah sebuah perasaan tidak nyaman yang memotivasi orang untuk mengambil langkah demi mengurangi ketidaknyamanan itu.

Dalam buku Teori Komunikasi yang dikemukakan West \& Turner (2008:135) ada empat asumsi dasar mengenai teori ini: (1) Manusia memiliki hasrat akan adanya konsistensi pada keyakinan, sikap, dan perilakunya, (2) Disonansi diciptakan oleh inkonsistensi psikologis, (3) Disonansi adalah perasaan tidak suka yang mendorong orang untuk melakukan tindakan dengan dampak yang dapat diukur, (4) Disonansi akan mendorong usaha untuk memperoleh konsonansi dan usaha untuk mengurangi disonansi. Usaha tersebut diwujudkan dalam tiga cara yang digunakan untuk mengurangi disonansi yang dirasakan menurut West \& Turner (2008:141), yaitu:

1. Mengurangi pentingnya keyakinan disonan

2. Menambahkan keyakinan yang konsonan

3. Menghapus disonansi dengan cara tertentu

\section{METODE PENELITIAN}

Metode pengkajian yang dilakukan dalam penelitian ini ialah melalui pendekatan kualitatif. Penelitian kualitatif pada hakekatnya adalah penelitian yang dilakukan hanya bersifat deskriptif yaitu untuk mengetahui atau menggambarkan kenyataan dari kejadian yang diteliti sehingga memudahkan peneliti untuk memperoleh data yang objektif. Subyek dalam penilitan ini ialah Mahasiswa Universitas Sriwijaya sebagai subyek yang secara langsung menjadi subyek utama penelitian ini. Sedangkan objek penelitian ini adalah Pola Pencarian Informasi Tentang Reproduksi Seksual Pada Mahsiswa Universitas Sriwijaya.

Metode Pengumpulan data yang digunakan pada penelitian ini adalah wawancara mendalam, observasi, dan dokumentasi. Pada penelitian ini yang menjadi informan adalah mahasiswi di semua Fakultas yang ada di Universitas Sriwijaya yaitu sebanyak 10 orang ditambah 1 orang mahasiswa Duta Generasi Berencana (Duta Genre) 2016 yang ditunjuk oleh Badan Kependudukan dan Keluarga Berencara Nasional (BKKBN). Teknik analisis data yang akan digunakan dalam penelitian ini adalah teknik filling system yang dikembangkan Winner \& Dominick. Menurut teknik ini, setelah seluruh data dikumpulkan oleh peneliti kemudian dilakukan analisis dengan membuat kategori-ketegori tertentu. Penelitian ini dilakukan di tahun 2017 dan di Universitas Sriwijaya yang berlokasi di Jalan Palembang-Prabumulih KM32 Inderalaya Ogan Ilir Sumatera Selatan

\section{HASIL DAN PEMBAHASAN}

\section{Informasi Demografis dan Kondisi Sosial Informan}

"Perilaku manusia tak lekang dari semesta yang menghidupinya". Pernyataan yang dikemukakan oleh TD Wilson ini sejalan dengan aliran psikologi behaviorisme yang mengatakan bahwa manusia adalah makhluk yang dibentuk oleh lingkungannya. Setidaknya ada tiga faktor yang dianggap penting untuk menjelaskan fenomena perilaku manusia, dalam 
konteks menemukan informasi (information seeking), yaitu konteks kehidupan pencari informasi, sistem informasi yang digunakannya, dan sumberdaya informasi yang mengandung berbagai informasi yang diperlukan. Ketiga aspek ini berada di dalam apa yang dinamakan "semesta pengetahuan" (Wilson; 1981). Selain itu pada risetnya yang lebih mutakhir, Wilson mengatakan bahwa terdapat beberapa hal yang mempengaruhi perilaku pencarian informasi seseorang, yaitu Kondisi Psikologis, Demografis, Peran di Masyarakat, Lingkungan, dan Karakteristik Sumber Informasi yang akan dibahas pada sub pokok bahasan selanjutnya. Adapun pada penelitian ini, semua informan berasal dari keluarga yang memiliki kemampuan ekonomi menengah kebawah. Dapat diihat pada tabel 1. Namun walaupun mereka berasal dari keluarga menengah, para informan mendapatkan kesempatan untuk menempuh pendidikan yang tinggi. Mahasiswa yang diwawancarai saat ini menetap di Inderalaya. Ogan Ilir yang tidak jauh dari kampus utama Universitas Sriwijaya. Setelah dilakukan observasi pada karakteristik para informan, diketahui bahwa semua informan memiliki akses terhadap internet melalui smartphone. Oleh karena itu mudah bagi informan untuk mencari tahu informasi seputar kesehatan reproduksi.

\section{Motivasi Informan dalam Melakukan Pencarian Informasi}

Perilaku pencarian informasi mahasiswa Universitas Sriwijaya merupakan manifestasi hayati mahasiswa sebagai individu dalam berinteraksi dengan lingkungan, yang dalam penelitian ini fokus pada konsep kesehatan reproduksi. Tingkah laku manusia sendiri merupakan sekumpulan perilaku yang dimiliki oleh manusia dan dipengaruhi oleh adat, sikap, emosi, nilai, etika, kekuasaan, persuasi, dan/atau genetika. Tingkah laku terjadi karena adanya motivasi atau dorongan (drive) yang mengarahkan individu untuk bertindak sesuai dengan kepentingan atau tujuan yang ingin dicapai. Karena tanpa dorongan tadi tidak akan ada suatu kekuatan yang mengarahkan individu pada suatu mekanisme timbulnya perilaku. Dorongan diaktifkan oleh adanya kebutuhan, dalam arti kebutuhan membangkitkan dorongan, dan dorongan ini pada akhirnya mengaktifkan atau memunculkan mekanisme perilaku.

Motivasi adalah kondisi atau keadaan yang mengaktifkan atau memberi dorongan kepada makhluk untuk bertingkah laku mencapai tujuan yang ditimbulkan oleh motivasi tersebut. Motivasi juga menjadi pendorong yang mengubah energi dalam diri manusia ke dalam bentuk suatu aktivitas nyata dalam mencapai tujuan tertentu. Adapun rangsangan motivasi berasal dari 2 hal, yaitu rangsangan dalam diri sendiri disebut motivasi instrinsik dan motivasi yang berasal dari rangsangan oleh faktor dari luar individu disebut Motivasi Ekstrinsik.

Dari hasil penelitian ini dapat diketahui bahwa mayoritas informan didorong oleh motivasi ekstrinsik dibandingkan dengan motivasi intrinsik dalam mencari informasi seputar kesehatan reproduksi. Salah satu informan bernama Gita (21 tahun) mengatakan bahwa tidak pernah mencari tahu informasi seputar kesehatan reproduksi seksual kepada tenaga medis kecuali saat kebetulan bertemu, berikut jawaban informan terkait pernyataan diatas:

"mungkin kalau bertanya secara sengaja itu belum pernah, namun pernah saya mempunyai urusan ke klinik disana saya sekalian bertanya dengan perawat dan dokter. Karena tante saya seorang perawat juga, jadi saya pernah konsultasi dengan beliau." (sumber : hasil wawancara pada tanggal 4 Oktober 2017 pukul 14.35)

Pendapat Informan Gita tersebut hampir senada dengan Informan Delliana (19 tahun), yang mengatakan bahwa : 
"pernah saya cari dinternet. Langsung googling. Tentang menstruasi. tidak lama, kalau sudah dapat intinya saya berhenti dan keluar. Yah sekitar 5-10 menit." (sumber : hasil wawancara tanggal 25 September 2017 pukul 09.12)

Adapun jawaban informan lainnya tidak jauh berbeda dengan kedua informan diatas. Mahasiswi di Universitas Sriwijaya melakukan pencarian informasi seputar reproduksi seksual sesekali dan dengan menggunakan media yang paling mudah di akses yaitu media sosial. Walaupun begitu ada dua informan yang secara aktif mencari informasi mengenai reproduksi seksual, hal ini dikarenakan mahasiswa tersebut merupakan mahasiswa keperawatan yang diberikan tugas oleh dosennya mengenai topik tersebut, dan mahasiswa yang lain merupakan Duta Generasi Berencana dari BKKBN sehingga memiliki tanggung jawab untuk menyebarkan informasi seputar reproduksi seksual kepada masyarakat. Informan yang saat ini menjalankan studi di jurusan keperawatan bernama Resti Aan (19 tahun) mengatakan sebagai berikut :

"untuk minggu-minggu ini saya sering membuka blog tentang kesehatan reproduksi karena memang ada tugas dari kampus tentang. Kami sedang belajar mengenai maternitas atau proses ibu hamil" (sumber : wawancara pada tanggal 26 September 2017 pukul 12.35)

Sementara Informan yang merupakan Duta Genre 2016 yaitu Tania (21 tahun) mengatakan:

"untuk saat ini saya bisa setiap hari saya mengakses dan mendapatkan informasi tentang kesehatan reproduksi, karena kebetulan saya tergabung di forum ini sehingga memang makanan saya setiap hari tentang kesehatan reproduksi ini." (sumber : wawancara pada tanggal 2 Oktober 2017 pukul 13.05)

Informan Resti dan Tania menghabiskan lebih banyak waktu untuk mencari informasi seputar reproduksi kesehatan, walaupun ada dorongan dari pihak eksternal untuk mereka melakukan pencarian informasi tersebut. Maslow dalam Atkinson (1983) berpendapat bahwa individu akan bertindak dengan cara-cara tertentu yang akan membawa ke arah pemuasan kebutuhan mereka. Dalam hal ini para informan pada penelitian ini memiliki persamaan alasan dalam mencari tahu informasi mengenai reproduksi kesehatan manusia yaitu rasa keingintahuan akan topik tersebut walaupun hal ini masih berada di ranah kognitif mereka. Semua kebiasaan individu dalam melakukan pencarian informasi membutuhkan motivasi yang cukup dalam pelaksanaannya. Namun perbedaannya akan terlihat pada proses dan hasil pencarian tersebut, informan yang memiliki motivasi rendah dalam mencari informasi seperti Gita dan Delliana akan mengerahkan usaha dan waktu yang lebih sedikit dalam mencari informasi dibandingkan dengan Resti dan Tania yang memiliki motivasi yang lebih tinggi dalam melakukan perilaku ini.

\section{KESIMPULAN DAN SARAN}

Dari hasil penelitian, dapat disimpulkan hal-hal sebagai berikut :

1. Mahasiwa di Universitas Sriwijaya memiliki perilaku pencarian informasi yang variatif, namun lebih cenderung pada pencarian pasif karena para informan tidak berusaha banyak untuk mencari tahu informasi seputar kesehatan reproduksi

2. Mahasiswa yang memiliki tanggung jawab berlebih, yaitu mahasiswa di fakultas kedokteran maupun mahasiswa yang aktif dalam kegiatan BkkbN melakukan pencarian informasi dengan aktif dan berlanjut 
3. Perilaku pencarian informasi mahasiswa Universitas Sriwijaya di dorong oleh motivasi ekstrinsik yang berasal dari luar pribadi mahasiswa. Selain itu motivasi untuk mencari informasi seputar kesehatan reproduksi adalah rasa ingin tahu dan tanggung jawab kepada status sebagai mahasiswa kesehatan dan yang terkait.

Walaupun penelitian ini telah menghasilkan temuan awal, peniliti masih harus mengembangkan analisis dan hasil lebih lanjut, khususnya memperdalam analisis pada sub bahasan pola pencarian informasi mahasiswa seputar kesehatan reproduksi.

\section{DAFTAR PUSTAKA}

Amy G, Miron dan Charles D.Miron.2006. Bicara Soal Cinta,Pacaran, dan Seks Remaja.Jakarta:Erlangga

Case, Donald O.. 2002. Looking for Information. London: Academic Press.

Dianawati, Ajen.203.Pendidikan Seks untuk Remaja. Tanggerang:CV.Andi Offset

Fajar, Marhaeni. 2009. Ilmu Komunikasi Teori \& Praktik. Yogyakarta : Graha Ilmu

Haffner,Linda J dan Danny J.Schust.2006. At a Glance Sistem Reproduksi Edisi Kedua.Jakarta : Erlangga

Lilttle John, Stephen W. 2009. Teori Komunikasi. Jakarta: Salmeba Humanika

Moleong. Lexy J. 2007. Metodologi Penelitian Kualitatif. Cetakan ke 24. Bandung: PT Remaja Rosdakarya.

Mulyana, Deddy. 2013. Metodologi Penelitian Kualitatif. Cetakan ke 8. Bandung: PT Remaja Rosdakarya.

Silalahi, Ulber. 2012. Metode Penelitian Sosial. Bandung: Anggota Ikapi

Severin, Warner J \& Tankard, James W, Jr. 2011. Teori Komunikasi Sejarah, Metode, dan Terapan di Dalam Media Massa. Jakarta: Kencana Media Group.

Turner Lynn \& Richard West. 2008. Pengantar Teori Komunikasi: Analisis dan Aplikasi. Jakarta:Mc Graw Hill.

Prosiding Simposium Nasional Komunikasi Kesehatan 2015.Fikom Unpad, Olel Susanne Dida dkk. Program Studi Hubungan Masyarakat Fakultasi Ilmu Komunikasi Universitas Padjajaran

https://www.bkkbn.go.id/

www.who.int/ 